\title{
Sagrada Escritura e Teologia Por uma responsabilidade social e comunitária da fé cristã
}

\author{
ABREU, Elza Helena de e ZACHARIAS, Ronaldo. (orgs.) \\ São Paulo: Paulinas, 2011. \\ (Col. Teologia, interdisciplinaridade e sociedade)
}

Rafael Zanata Albertini, sdb*

A obra aqui abordada consiste no primeiro livro da coleção "Teologia, interdisciplinaridade e sociedade", cujo objetivo é oferecer um meio de diálogo das reflexões teológicas mais recentes com outras ciências e a realidade circundante, tendo por recorte temático o empenho prático da fé na esteira do Concílio Vaticano II. Pode-se dizer que esse projeto é seguido à risca por cada artigo escolhido.

Três partes compõem o livro. A primeira tem por foco a Palavra de Deus e sua relação com a Teologia. A segunda parte mira o tema da formação teológica, com a discussão sobre o lugar que nela ocupam a Palavra de Deus e as dimensões intelectuais e pastorais. A última

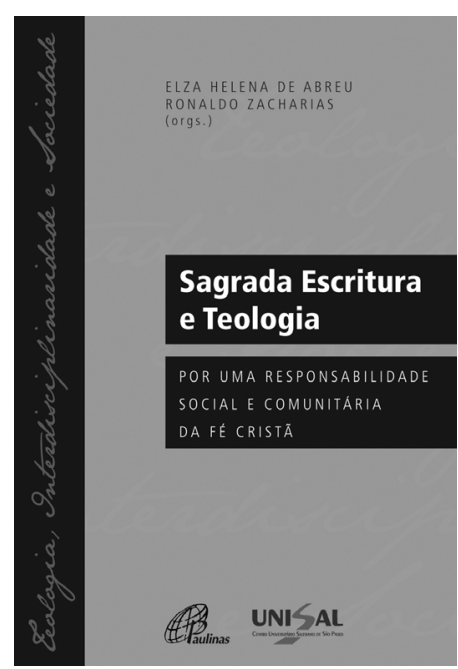
seção centra-se na peculiaridade da Teologia e sua implicação na responsabilidade social.

Rafael Rodrigues, em sua perspectiva de teólogo biblista, investiga como a Palavra de Deus é entendida na própria Escritura judaico-cristã e ao longo da história da Igreja, particularmente na Igreja latino-americana, com seu modo peculiar de relacionar a Bíblia com a realidade e a comunidade. Em

Licenciado em Filosofia pela UCDB (Universidade Católica Dom Bosco, de Campo GrandeMS) em 2005. Graduando do $4^{\circ}$ ano de Teologia, no Campus Pio XI do UNISAL (Centro Universitário Salesiano de São Paulo), Lapa, São Paulo-SP. 
seu outro artigo, da mesma parte, o autor se pergunta pela função social da Teologia, tanto sistemática quanto exegética. A partir dos Padres da Igreja e teólogos dos últimos séculos, ele aponta a necessidade de uma hermenêutica teológica que escape de leituras da Escritura em viés fundamentalista, autoritário, exclusivamente exegético ou desarticulado da comunidade.

Johan Konings faz uma importante distinção entre a Palavra de Deus e a Bíblia, destacando que aquela se expressa nesta, sem, porém, a ela se reduzir. Qual uma espiral, a experiência de Deus é feita Teologia e um desses momentos é a escrituração da Palavra, o que faz da Bíblia a alma dos estudos teológicos.

Pe. Milton Schreiber atém-se à questão do método teológico e propõe a Teologia como filha das "núpcias ente o Logos e a Escritura acolhida na fé". Sua preocupação, do começo ao fim, é demonstrar a unidade entre o texto bíblico e a interpretação teológica, dos quais o ser humano se serve para acessar o mistério de Deus.

À luz do Vaticano II e do Sínodo sobre a Palavra de Deus, Francisco Catão diz que é preciso revisar a formação, tendo por baliza a fidelidade ao espírito da Tradição, distinguindo-o de suas formas históricas. Para tanto, ele atenta para dois riscos: a materialização da Palavra (fundamentalismo) ou a instrumentalização dela (supervalorização da autoridade eclesial).

Valendo-se, sobretudo de documentos do Magistério, em suas várias instâncias, Dom Eduardo Pinheiro destaca o pedido insistente da Igreja por uma formação integral, sólida e exigente, que tem nos estudos o meio privilegiado para o conhecimento de Jesus Cristo. A exemplo do Cura d'Ars, o saber deve fazer-se vida para gerar uma "sábia humildade".

Na reflexão do Padre Luiz Eduardo Baronto, impõe-se a questão: como entender os estudos como um serviço pastoral? Ele afirma que somente a boa vontade não basta para uma boa pastoral, senão uma ação qualificada, que demanda uma formação excelente, não-fragmentada, significativa e inculturada. Várias opções concretas concluem o artigo.

Magno Vilela trata da especificidade da Teologia cristã e busca nos Padres da Igreja as pistas para seu raciocínio. Na frase de Tertuliano ecclesia ab apostolis, apostoli a Christo, Christo a Deo - ele reconhece a preocupação, essencialmente histórica, que a Teologia tem para com sua origem, que é o próprio Logos, enquanto fonte da verdade.

138 Revista de Cultura TeológIcA - v. 19 - N. 75 - JUL/SET 2011 
Nestes tempos de crise, Agenor Brighenti enxerga a oportunidade de se demonstrar a responsabilidade social do ministério do teólogo, no duplo e irrenunciável diálogo com a Igreja e com o mundo. Sob o marco da teologia latino-americana, ele destaca o caráter profético do Evangelho, enquanto potente força transformadora da realidade.

Fernando Altemeyer encerra os artigos com um importante empenho para a teologia: perguntar-se pelas aflições das pessoas de hoje e buscar-Ihe respostas. Da Palavra de Deus, nasce uma "teologia da compaixão" que não passa ao largo da realidade, mas a reflete profundamente, como expoentes latino-americanos não cansaram de fazê-lo.

Diante do que se vê na obra, em seu conjunto e em cada uma das partes, é justo reconhecer seu valor para cumprir aquilo a que se destina: propor o diálogo da ciência teológica com a pluralidade de saberes e sinais dos tempos. Diferente do que se possa pensar em alguns ambientes, as reflexões revelam a face da Teologia aberta à pluralidade e à novidade, por conta mesmo de sua origem: o Verbo de Deus que, Imutável, renova e revigora todos os seres. Quiçá essa rica produção, que apresenta conteúdos consistentes em linguagem acessível, seja bem recebida pelos diversos destinatários a que se propõe! 